\title{
Neural networks and fuzzy inference systems for predicting water consumption time series
}

Mehmet Ali Yurdusev • Mahmut Frat •

Mustafa Erkan Turan • B. Gultekin Sinir

Published online: 5 June 2009

(C) Springer-Verlag 2009

This article has been published OnlineFirst, but is withdrawn at the request of the authors.

This article has been published OnlineFirst, but is withdrawn at the request of the authors.

M. A. Yurdusev $(\bowtie) \cdot$ M. E. Turan · B. Gultekin Sinir Civil Engineering Department, Celal Bayar University,

Manisa, Turkey

e-mail: yurdusev@bayar.edu.tr

M. Firat

Civil Engineering Department, Pamukkale University,

Denizli, Turkey 